\title{
Soybean Seed Treatment with Nickel Improves Biological Nitrogen Fixation and Urease Activity
}

\author{
José Lavres ${ }^{1 *}$, Guilherme Castro Franco ${ }^{1}$ and Gil M. de Sousa Câmara ${ }^{2}$ \\ ${ }^{1}$ Center for Nuclear Energy in Agriculture, University of Sao Paulo, Piracicaba, Brazil, ${ }^{2}$ Department of Crop Science, Luiz de \\ Queiroz College of Agriculture, University of Sao Paulo, Piracicaba, Brazil
}

\section{OPEN ACCESS}

Edited by:

Naser A. Anjum,

University of Aveiro, Portugal

Reviewed by:

Mirza Hasanuzzaman,

Sher-e-Bangla Agricultural University,

Bangladesh

M. Iqbal R. Khan,

International Rice Research Institute,

Philippines

*Correspondence:

José Lavres

jlavres@usp.br

Specialty section:

This article was submitted to

Environmental Toxicology,

a section of the journal

Frontiers in Environmental Science

Received: 31 December 2015 Accepted: 02 May 2016

Published: 19 May 2016

Citation:

Lavres J, Castro Franco G and

de Sousa Câmara GM (2016) Soybean Seed Treatment with Nickel Improves Biological Nitrogen Fixation and Urease Activity.

Front. Environ. Sci. 4:37. doi: 10.3389/fenvs.2016.00037
Nickel (Ni) is an essential micronutrient required for plants' metabolism due to its role as a structural component of urease and hydrogenase, which in turn perform nitrogen (N) metabolism in many legume species. Seed treatment with cobalt, molybdenum and Bradyrhizobium strains has been widely practiced to improve crops. Additionally, seed treatment together with $\mathrm{Ni}$ fertilization of soybean might improve the efficiency of biological nitrogen fixation (BNF), boosting grain dry matter yield, and $\mathrm{N}$ content. The objective of this study was to evaluate the effect of soybean seed treatment with $\mathrm{Ni}$ rates $\left(0,45,90,135,180,360\right.$, and $\left.540 \mathrm{mg} \mathrm{kg}^{-1}\right)$ on $\mathrm{BNF}$, directly by the ${ }^{15} \mathrm{~N}$ natural abundance method $\left(\delta^{15} \mathrm{~N} \%\right.$ ) and by measurement of urease [E.C. 3.5.1.5] activity, as well as indirectly by nitrogenase (N-ase) activity [E.C. 1.18.6.1]. Soybean plants (cultivar $B M X$ Potência RR) were grown in a sandy soil up to the R7 developmental stage (grain maturity), at which point the nutrient content in the leaves, chlorophyll content, urease, and $\mathrm{N}$-ase activities, $\mathrm{Ni}$ and $\mathrm{N}$ content in the grains, nodulation (at R1-flowering stage), as well as the contribution of biological nitrogen fixation (BNF; $\delta^{15} \mathrm{~N} \%$ ) were evaluated. The proportion of $\mathrm{N}$ derived from $\mathrm{N}_{2}$ fixation varied from 77 to $99 \%$ using the natural ${ }^{15} \mathrm{~N}$ abundance method and non-nodulating Panicum miliaceum and Phalaris canariensis as references. A Ni rate of $45 \mathrm{mg} \mathrm{kg}^{-1}$ increased BNF by $12 \%$ compared to the control. The increased $\mathrm{N}$ uptake in the grains was closely correlated with chlorophyll content in the leaves, urease, and $\mathrm{N}$-ase activities, as well as with nodulation. Grain dry matter yield and aerial part dry matter yield increased, respectively, by 84 and $51 \%$ in relation to the control plants at $45 \mathrm{mg} \mathrm{kg}^{-1} \mathrm{Ni}$ via seed treatment. Despite, Ni concentration was increased with $\mathrm{Ni}$-seed treatment, Ni rates higher than $135 \mathrm{mg} \mathrm{kg}^{-1}$ promoted negative effects on plant growth and yield. In these experimental conditions, seed treatment with low $\mathrm{Ni}$ rates caused higher dry matter yield of plants and grains, $\mathrm{N}$ content in the grains, and in the aerial part by increasing of BNF.

Keywords: ${ }^{15} \mathrm{~N}$ natural abundance method, nitrogenase, nitrogen uptake, nodule fresh weight, SPAD index

\section{INTRODUCTION}

In its 10th Brazilian grain harvest survey, The Brazilian Company Supply (Companhia Nacional de Abastecimento (Conab), 2014) estimated the country's harvest in the 2014-2015 growing season at 206.3 million metric tons, produced by a tilled area of 57.5 million hectares. After the harvest was finished, the nation's soybean production set a new record, at 96.2 million tons, from 31.9 million 
hectares, with average yield of $3016 \mathrm{~kg} \mathrm{ha}^{-1}$. The conduction of basic and applied research and application of new technologies in recent decades has allowed adaptation of soybean to virtually all regions of the country, from the state of Rio Grande do Sul in the south to the tropical equatorial latitudes in the north. The expansion of soybean growing in Brazil has always been closely associated with scientific advances and the availability of new technologies, the highlights being genetic gains provided by various improvement programs, better chemical management of tropical soils, improved plant nutrition, increase of no-till farming methods, development of more efficient chemicals to protect crops from pests, diseases and weeds, and the offer of seeds with better physiological and phytosanitary quality (Alves et al., 2003; Sentelhas et al., 2015).

In the area of plant nutrition, important progress has been made to improve the interaction of soybean plants with bacteria belonging to the Bradyrhizobium genus, which are highly efficient in promoting BNF. Through infection of the root system, they form nodules within which the bradyrhizobia reduce $\mathrm{N}_{2}$ to $\mathrm{NH}_{3}$ (Cadisch et al., 2000; González-Guerrero et al., 2014). Biologic nitrogen fixation (BNF) is one of the most effective alternatives to reduce overuse of nitrogen fertilizers for improving plant nutrition as well as to reduce environmental impacts (Jensen and Hauggaard-Nielsen, 2003; Campo et al., 2009).

Nitrogen $(\mathrm{N})$ is the nutrient required in greatest quantity by soybean plants, with grain concentrations ranging from 45 to $65 \mathrm{~g}$ $\mathrm{kg}^{-1}$. To achieve average yield of $3000 \mathrm{~kg} \mathrm{ha}^{-1}$, it is estimated that application of $240 \mathrm{~kg} \mathrm{ha}^{-1}$ of $\mathrm{N}$ is necessary (Alves et al., 2003). In Brazil, it has been estimated that rates of $\mathrm{N}_{2}$ fixation in soybean can exceed $300 \mathrm{~kg}$ of $\mathrm{N} \mathrm{ha}^{-1}$, providing up to $94 \%$ of total plant $\mathrm{N}$ (Hungria et al., 2005, 2006). Therefore, good BNF is fundamental to supply the $\mathrm{N}$ demand, so improvements in this respect have been a huge boon to Brazilian farmers due to savings on nitrogen fertilizers, which cost between US\$ 15.5 and US\$ 18.0 billion a year-depending on the exchange rate and the unit fertilizer price-(Hungria et al., 2005, 2006). In leguminous plants, metal cofactors are required by the endosymbiotic rhizobia located in the cortical cells of the root system (González-Guerrero et al., 2014). However, the low availability of cationic micronutrients like $\mathrm{Cu}^{2+}, \mathrm{Fe}^{2+}, \mathrm{Mn}^{2+}$, and $\mathrm{Ni}^{2+}$, especially in tropical Oxisols that have received excessive lime doses, can result in nutritional disorders (e.g., deficiency induced by $\mathrm{Mn}$ and $\mathrm{Fe}$ in soils in Cerrado regions), reducing the nitrogen fixation capacity (Fageria and Stone, 2008).

At the core of this process are a number of metalloproteins that catalyze and provide energy for the conversion of atmospheric $\mathrm{N}_{2}$ to ammonia, eliminate free radicals produced by this process, and create the microaerobic conditions required by these reactions (González-Guerrero et al., 2014). Among molybdenum (Mo), cobalt (Co), and iron (Fe), another micronutrient that is important in the BNF process is nickel (Ni), which is involved in the expression and biosynthesis of hydrogenase (Klucas et al., 1983). Studies indicate that the level of hydrogenase activity can be limited in agricultural soils due to low $\mathrm{Ni}$ availability ( $<0.2 \mathrm{mg} \mathrm{kg}^{-1}$, extracted by DTPA). Low levels of available $\mathrm{Ni}$ in the soil affect the hydrogenase activity, which can be remediated by application of $10 \mathrm{mg} \mathrm{dm}^{-3}$ of $\mathrm{Ni}$ (Ureta et al.,
2005). However, it has been pointed out in the literature that $\mathrm{Ni}$ requirement in all plants vary and it depends on plant species and varieties (Seregin and Kozhevnikova, 2006).

Despite plants' requirement for $\mathrm{Ni}$ and the demonstration that it is essential by various authors, there is no official recommendation of nickel rate for treatment of soybean seeds. Normally the treatment of seeds with micronutrients has been done with the goal of enhancing BNF, and in this respect, minimum rates of Mo and Co have already been defined by researchers and are widely applied by farmers. Besides, in Brazil, the law that controls fertilizers trade included $\mathrm{Ni}$ on the list of micronutrients in which $\mathrm{Ni}$ was designed for application to soil, seeds, or foliar. However, experiments are still necessary to define the Ni rates for treatment of soybean seeds.

In fact, very little research has been done about the influence of $\mathrm{Ni}$ on the symbiotic system of BNF. Therefore, this study evaluated the effect of adding $\mathrm{Ni}$, through treatment of soybean seeds, on the BNF (directly by the ${ }^{15} \mathrm{~N}$ natural abundance method $\delta^{15} \mathrm{~N} \%$ ), quantities of $\mathrm{Ni}$ in the plants, urease and nitrogenase activities (indirectly methods) and production of biomass by the roots, aerial parts, and grains.

\section{MATERIALS AND METHODS}

The experiment was conducted in February to June 2014, in a greenhouse in the research area of the Department of Biosystems Engineering of Luiz de Queiroz Superior School of Agriculture (ESALQ), part of the University of São Paulo (USP). The soil for the experiment, classified as Red-Yellow Latosol (Oxisol; Embrapa, 2006), was collected from the surface layer $(0-20 \mathrm{~cm})$ of a cultivated area in the municipality of Piracicaba, São Paulo state. The texture was sandy, with $160 \mathrm{~g} \mathrm{~kg}^{-1}$ of clay, $20 \mathrm{~g} \mathrm{~kg}^{-1}$ of silt, and $820 \mathrm{~g} \mathrm{~kg}^{-1}$ of sand, of which $550\left(\mathrm{~g} \mathrm{~kg}^{-1}\right)$ was fine sand and $270\left(\mathrm{~g} \mathrm{~kg}^{-1}\right)$ was coarse sand. The chemical characteristics are presented in Table $\mathbf{1}$.

The species grown was Glycine max (L.) Merrill, cultivar $B M X$ Potência $R R$. This genotype is one of the most widely planted in Brazil, and presents indeterminate growth habit, early cycle, and maturity group number 6.7. The experiment started on February 17, 2014 and the plants were harvested at the end of the reproductive cycle, corresponding to reproductive phenological stage of fruit and seed ripening-(R7; Fehr et al., 1971).

The plants were grown in plastic pots with capacity of 3.0 $\mathrm{dm}^{3}$ of soil, with two plants per pot. The soil utilized had not been previously cultivated with legumes. This fact, along with the previous experience of the student research assistants in experiments with soybean plants in the same greenhouse (who reported difficulty in initial development of the plants due to lack of $\mathrm{N}$ ), caused the decision to assure initial supply of all the treatments with a small dose of $\mathrm{N}$-urea $\left(10 \mathrm{mg} \mathrm{dm}^{-3}\right)$, equivalent to a rate of $20 \mathrm{~kg} \mathrm{ha}^{-1}$, to supply the needs for initial development of the plants (Hatfield et al., 1974; Pierozan et al., 2015). The dose of $\mathrm{K}$, in the form of $\mathrm{K}_{2} \mathrm{SO}_{4}$, was $150 \mathrm{mg} \mathrm{dm}^{-3}$, applied at the time of sowing, and later as top dressing during phenological stages V1 and V5 (first and fifth leaflet appearance, respectively; Fehr et al., 1971). The $\mathrm{P}$ rate, in the form of $\mathrm{Ca}\left(\mathrm{H}_{2} \mathrm{PO}_{4}\right)_{2}{ }^{\circ}$ 
TABLE 1 | Soil chemistry analysis of Red-Yellow Latosol (Oxisol) before soybean sowing (beginning of the experiment).

\begin{tabular}{|c|c|c|c|c|c|c|c|c|c|c|}
\hline $\begin{array}{l}\text { Soil layer } \\
\text { cm }\end{array}$ & $\begin{array}{c}\mathrm{pH} \\
\mathrm{CaCl}_{2}\end{array}$ & $\begin{array}{c}{ }^{\text {aOM }} \\
\mathrm{g} \mathrm{kg}^{-1}\end{array}$ & $\begin{array}{c}P \\
\mathrm{mg} \mathrm{kg}^{-1}\end{array}$ & $\mathbf{K}$ & $\mathrm{Ca}$ & Mg & Al & $\mathrm{H}+\mathrm{Al}$ & CEC & $\begin{array}{l}\text { V } \\
\%\end{array}$ \\
\hline \multirow[t]{2}{*}{$0-20$} & 5.6 & 9 & 19 & 0.6 & 24 & 6 & 0 & 13 & 44.3 & 70 \\
\hline & & & \multicolumn{8}{|c|}{$-\mathrm{mg} \mathrm{dm}^{-3}$} \\
\hline 0-20 & 2.5 & 0.51 & 0.6 & 23 & 4 & 0.9 & 0.03 & & & \\
\hline
\end{tabular}

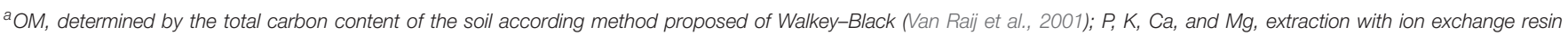

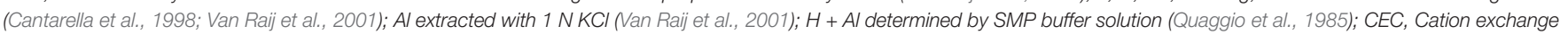
capacity; $V$, bases saturation. ${ }^{\S} \mathrm{Ni}$, DTPA pH 7.0.

$\mathrm{H}_{2} \mathrm{O}$, was $200 \mathrm{mg} \mathrm{dm}^{-3}$. The micronutrients $\left(\mathrm{mg} \mathrm{dm}^{-3}: 0.5\right.$ of $\mathrm{B}$ - as boric acid; 2.0 of $\mathrm{Fe}$-as EDTA; 1.0 of $\mathrm{Cu}$; 5.0 of $\mathrm{Mn}$, and 5.0 of $\mathrm{Zn}$, as zinc sulfate), were applied the day before planting. The seeds ( $1 \mathrm{~kg}$ of cultivar BMX Potência $R R$ ) were treated with a sugared solution containing molybdenum and cobalt, at rates of 450 and $45 \mathrm{mg} \mathrm{kg}^{-1}$, respectively, followed by application of $\mathrm{Ni}$ for each treatment, at rates of $0,45,90$, $135,180,360$, and $540 \mathrm{mg} \mathrm{kg}^{-1}$ of seeds-it corresponds to 0 , $2.5,5.0,7.5,10,20$, and $30 \mathrm{~g}$ per hectare -, in the form of nickel sulfate. The solution had been previously fortified with $2.0 \mathrm{~mL} \mathrm{~kg}^{-1}$ of the commercial liquid products "Semia 5019" and "Semia 5079," which contain strains of Bradyrhizobium elkanii and Bradyrhizobium japonicum, respectively. Afterward, the seeds were moistened with the sugared solution at $10 \%$, with the addition of $6.0 \mathrm{~mL}$ of solution to the total volume of treated seeds $(1 \mathrm{~kg})$, with the objective of improving the adherence of the inoculant on the seeds (Embrapa, 2011). The seeds were treated early in the morning and then were sown at a depth of $2.0 \mathrm{~cm}$ in the pots. The remaining treated seeds not planted were discarded in a suitable place. No fungicide or insecticide was added at the time of seed treatment. The soil moisture was corrected during the experiment to keep it at $60 \%$ of maximum water retention capacity.

The plants were harvested at phonological reproductive stage of fruit and seed ripening (R7; Fehr et al., 1971). Two species of were grown in the same soil in the greenhouse that were not atmospheric nitrogen fixers-common millet ( $P$. miliaceum) and canary grass ( $P$. canariensis) - to serve as reference to indicate enrichment of ${ }^{15} \mathrm{~N}$ available in the soil (Peoples et al., 1989; Boddey et al., 2001; Brito et al., 2009; Urquiaga et al., 2012).

The experimental design was fully randomized, with seven treatments (Ni rates) and eight repetitions, four conducted only until the reproductive phenological stage of inflorescence emergence-(R1; Fehr et al., 1971), when some of the plants were harvested to evaluate the nodular development of the root system and enzyme activity of nitrogenase and urease. The rest of the plants were maintained until the phonological reproductive stage of fruit and seed ripening (R7; Fehr et al., 1971), to measure the dry weight of the roots, aerial parts and grains. Each pot with two plants was an experimental unit. The pots were arranged on a bench raised $10 \mathrm{~cm}$ from the floor.

The leaves used for diagnosis of the concentrations of nutrients (third or fourth leaf from the tip of the main stem with petiole) were collected at reproductive phenological stage of inflorescence emergence-(R1; Fehr et al., 1971), about 45 days after emergence of the plantlets. The material was placed in labeled paper bags and dried in an oven at $65^{\circ} \mathrm{C}$ for $72 \mathrm{~h}$ and then weighed on a precision scale. The dried material was ground in a Wiley mill, passed through a sieve with mesh of $1 \mathrm{~mm}$ and sent to the laboratory for measurement of the concentrations of macro and micronutrients, according to the method described by Malavolta et al. (1997).

As of the start of senescence (R3-R4; Fehr et al., 1971), the fallen leaves were collected and weighed to determine the final dry weight and also were submitted to chemical analysis. About 105 days after planting (reproductive phenological stage R7), the plants were harvested and separated into two portions, the grains and remaining aerial part (stems, pods, green, and dead leaves), for subsequent nutrient concentration tests. The chlorophyll in the leaves was quantified nondestructively with a portable SPAD 502 chlorophyll meter (Minolta, Japan). The readings were taken using the middle third of the diagnostic plants in phenological stage $\mathrm{R} 1$, and the average was computed of 30 readings per plant.

The BNF was quantified by the technique of natural abundance of ${ }^{15} \mathrm{~N}$ (Shearer and Kohl, 1986; Cadisch et al., 2000). This technique is based on the fact that generally the $\mathrm{N}$ in the soil is slightly richer in the isotope ${ }^{15} \mathrm{~N}$ in comparison with the $\mathrm{N}_{2}$ in the air (Shearer and Kohl, 1986; Cadisch et al., 2000). The $\mathrm{N}$ from the air contains about $0.3663 \%{ }^{15} \mathrm{~N}$ and the rest (99.6337\%) is ${ }^{14} \mathrm{~N}$ (Boddey et al., 2001). However, due to the isotopic discrimination that occurs during the transformations of nitrogen in the soil-plant system, both can present ${ }^{15} \mathrm{~N}$ values that are slightly higher than found in the atmosphere. These variations are extremely small, so that each unit of delta ${ }^{15} \mathrm{~N}$ is considered to have natural abundance divided by one thousand, i.e., 0.0003663 atom $\%$ of ${ }^{15} \mathrm{~N}$ in excess (Shearer and Kohl, 1986; Cadisch et al., 2000). Species able to obtain most of the $\mathrm{N}$ necessary for their nutrition will have $\delta^{15} \mathrm{~N}$ values very near zero, since the largest part of the $\mathrm{N}$ will come from the air, which is the standard of the technique and contains $0.3663 \%{ }^{15} \mathrm{~N}$, meaning zero excess units of $\delta^{15} \mathrm{~N}$ (Shearer and Kohl, 1986; Cadisch et al., 2000; Boddey et al., 2001). On the other hand, non-fixing $\mathrm{N}$ species (control plants) grown in the same soil will have higher $\delta^{15} \mathrm{~N}$ values, near those in the soil, since all or most of the $\mathrm{N}$ necessary for their development will be derived from the soil. Like other isotopic techniques, this one depends on the basic premise that fixing 
and non-fixing plants, grown in the same soil, absorb $\mathrm{N}$ with the same marking with ${ }^{15} \mathrm{~N}$ (Shearer and Kohl, 1986; Boddey et al., 2001; Guimaraes et al., 2008). This limitation was overcome by selecting reference species with root development and $\mathrm{N}$ demand similar to soybean. The proportion of $\mathrm{N}$ in the plants that can fix $\mathrm{N}_{2}$ from the air by the BNF process was calculated by the equation of Shearer and Kohl (1986):

$$
\begin{aligned}
\% \mathrm{BNF}= & 100 \times\left(\delta^{15} \mathrm{~N} \text { reference }-\delta{ }^{15} \mathrm{~N} \text { soy }\right) \\
& /\left(\delta{ }^{15} \mathrm{~N} \text { reference }-\mathrm{B}\right)
\end{aligned}
$$

Where:

$$
\begin{aligned}
\% \mathrm{BNF}= & \text { percentage of } \mathrm{N} \text { obtained from } \mathrm{BNF} \\
& \text { in the soybean plants; }
\end{aligned}
$$

$\delta^{15} \mathrm{~N}$ reference $=$ natural abundance of ${ }^{15} \mathrm{~N}$ in the reference plant (non-fixer of $\mathrm{N}$ );

$\delta^{15} \mathrm{~N}$ soy $=$ natural abundance of ${ }^{15} \mathrm{~N}$ in soybean plants.

$\mathrm{B}=$ fractional contribution of ${ }^{15} \mathrm{~N}$ in relation to ${ }^{14} \mathrm{~N}$ by the soybean plants in absorbing $\mathrm{N}$ from the soil. In this experiment, we used the average value of $-1.17 \%$ obased on the data obtained by Guimaraes et al. (2008). Subsamples of dried and ground material sampled were analyzed for $\% \mathrm{~N}$ and $\delta^{15} \mathrm{~N}$ in an automated mass spectrometer coupled to an ANCA-GSL $\mathrm{N}$ analyzer (Sercon Co., UK). The total $\mathrm{N}$ concentrations and ${ }^{15} \mathrm{~N} /{ }^{14} \mathrm{~N}$ isotope ratio were calculated according to the method of Barrie and Prosser (1996).

The fresh tissue samples were collected in the morning (around 8:00 a.m.), placed in plastic bags and then in polystyrene foam boxes to maintain the temperature and enzyme activity low. These samples consisted of the leaves used for foliar diagnosis of chlorophyll content, collected at stage R1. The urease activity in vivo was measured by an adaptation of the methods described by Hogan et al. (1983). The plant material (200 mg of green leaves, cut into "slices" with width of $1 \mathrm{~mm}$ ) were placed in a medium of $8 \mathrm{~mL}$ of $\mathrm{NaH}_{2} \mathrm{PO}_{4}$ buffer with urea $\mathrm{pH} 7.4$ and incubated for $3 \mathrm{~h}$ at $30^{\circ} \mathrm{C}$, protected from light in aluminum foil and kept under constant agitation. In a test tube containing $0.5 \mathrm{~mL}$ of the extract obtained after incubation, $2.5 \mathrm{~mL}$ of Reagent I (phenol 0.1 mol L ${ }^{-1}$, sodium nitroprusside $-170 \mu \mathrm{mol} \mathrm{L}^{-1}$ ) and $2.5 \mathrm{~mL}$ of Reagent II $\left(\mathrm{NaOH} 0.125 \mathrm{~mol} \mathrm{~L}^{-1}, \mathrm{Na}_{2} \mathrm{HPO}_{4} .12 \mathrm{H}_{2} \mathrm{O} 0.15 \mathrm{~mol}\right.$ $\mathrm{L}^{-1}, \mathrm{NaOCl}-3 \% \mathrm{Cl}_{2}$ ) were added. The tubes were closed with stoppers to avoid loss of $\mathrm{NH}_{3}$ and placed in a water bath at $37^{\circ} \mathrm{C}$ for $35 \mathrm{~min}$. After this interval, the reaction was measured by colorimetry in a spectrophotometer at $625 \mathrm{~nm}$. The urease activity was determined by the quantity of ammonium $\left(\mathrm{NH}_{4}^{+}\right)$ produced, and the values were compared with a standard curve, previously plotted using $\mathrm{NH}_{4} \mathrm{Cl}$ as a standard for ammonium. The results obtained were expressed in $\mu \mathrm{mol} \mathrm{NH}_{4}^{+} \mathrm{g}^{-1} \mathrm{FW} \mathrm{h}^{-1}$.

The BNF was also ascertained indirectly by the acetylene reduction assay (ARA; Boddey et al., 2001). For this, the plants were collected in stage R1 (Fehr et al., 1971) and the roots containing nodules were carefully separated from the soil, after which the nodules were placed in hermetically sealed flasks. Then a needle and syringe were used to withdraw about $10 \%$ of the gas phase from each flask (corresponding to a volume of $1 \mathrm{~mL}$ ) and the same quantity of acetylene gas, with 98-99\% purity, was injected in the flask. Due to the large variations of the ideal incubation time with acetylene gas described in the literature, we chose $1 \mathrm{~h}$, so as not to overestimate the enzyme activity and to avoid possible problems of conversion of the acetylene gas into ethylene by the composition of the stoppers utilized to seal the flasks. To measure the concentration of ethylene gas formed in the flask, $1 \mathrm{~mL}$ of the gas phase was withdrawn with a needle and syringe with capacity of $2.5 \mathrm{~mL}$ and injected in a gas chromatograph (Thermo Scientific Finnigan Trace ${ }^{\mathrm{TM}}$ GC 2000 model), with two Porapack N columns (Boddey et al., 2001). The run time to measure the ethylene concentration was $1 \mathrm{~min}$.

At the end of the experiment, the remaining plants were harvested and separated into aerial part (leaves, stems, and pods) and grains. The material was identified, placed in paper bags and dried in an oven at $65^{\circ} \mathrm{C}$ for $72 \mathrm{~h}$. The two dried plant portions (grains and aerial parts) were weighed on a scale with precision of $0.001 \mathrm{~g}$.

Then the dried material was ground in a Wiley mill and passed through a sieve with mesh size of $1 \mathrm{~mm}$ to perform the chemical analyses of macro and micronutrients in the tissues according to the method described by Malavolta et al. (1997). The quantities of nutrients accumulated in the plant tissues were calculated by multiplying the concentration by the dry matter weight of each plant part.

The statistical analyses were performed with the SAS Institute (2009). The data were first analyzed by calculating the descriptive parameters mean, standard deviation, and coefficient of variation. When necessary, the data were transformed to satisfy the criteria of homogeneity and homoscedasticity. The data were also submitted to analysis of variance by the $F$-test. When the effect of the Ni rates was significant, we applied linear and quadratic regression analysis. In all analyses, the level of significance was considered to be $5 \%$.

\section{RESULTS}

The temperature and relative humidity conditions in the greenhouse were favorable to the development of the soybean plants, without any extreme conditions that could have impaired their development (Figure 1). The temperature varied from de 20 to $39^{\circ} \mathrm{C}$, with average of $29^{\circ} \mathrm{C}$, and the relative humidity remained near $80 \%$, values considered favorable for development of the species.

The application of the $\mathrm{Ni}$ doses via seeds influenced the leaf concentrations of the macronutrients $\mathrm{N}, \mathrm{P}, \mathrm{K}, \mathrm{Ca}, \mathrm{Mg}$, and $S$ (Table 2). We observed a quadratic effect for the leaf concentrations of $\mathrm{P}, \mathrm{K}, \mathrm{Mg}$, and $\mathrm{Ca}$, in general with a reduction of the leaf concentrations of these nutrients at the higher Ni rates. On the other hand, we observed a linear effect for concentration of $\mathrm{N}$ and $\mathrm{S}$ in the leaves, varying from 25.8 to $34 \mathrm{~g} \mathrm{~kg}^{-1}$ and from 2.1 to $3.8 \mathrm{~g} \mathrm{~kg}^{-1}$, respectively, at $\mathrm{Ni}$ rates of 0 and 540 $\left(\mathrm{mg} \mathrm{kg}^{-1}\right)$. The concentrations of $\mathrm{P}$ ranged from 2.1 to 3.1 ( $\mathrm{g}$ $\left.\mathrm{kg}^{-1}\right)$, respectively, for rates of 0 and $540\left(\mathrm{mg} \mathrm{kg}^{-1}\right)$ of $\mathrm{Ni}$ in seeds. The concentrations of $\mathrm{K}$ varied from 24 to $35\left(\mathrm{~g} \mathrm{~kg}^{-1}\right)$, respectively, at doses of 0 and $360\left(\mathrm{mg} \mathrm{kg}^{-1}\right)$. Ca and $\mathrm{Mg}$ 
varied, respectively, from 16 to 24 and from 3.3 to $5.1\left(\mathrm{~g} \mathrm{~kg}^{-1}\right)$, respectively, at $\mathrm{Ni}$ rates of 0 and $135\left(\mathrm{mg} \mathrm{kg}^{-1}\right.$; Table 2$)$.

Seed-Ni treatments have changed the concentration of micronutrients $\mathrm{B}, \mathrm{Cu}, \mathrm{Fe}, \mathrm{Mn}, \mathrm{Ni}$, and $\mathrm{Zn}$ in the leaves (Table 2). It was observed linear effect for concentration of all

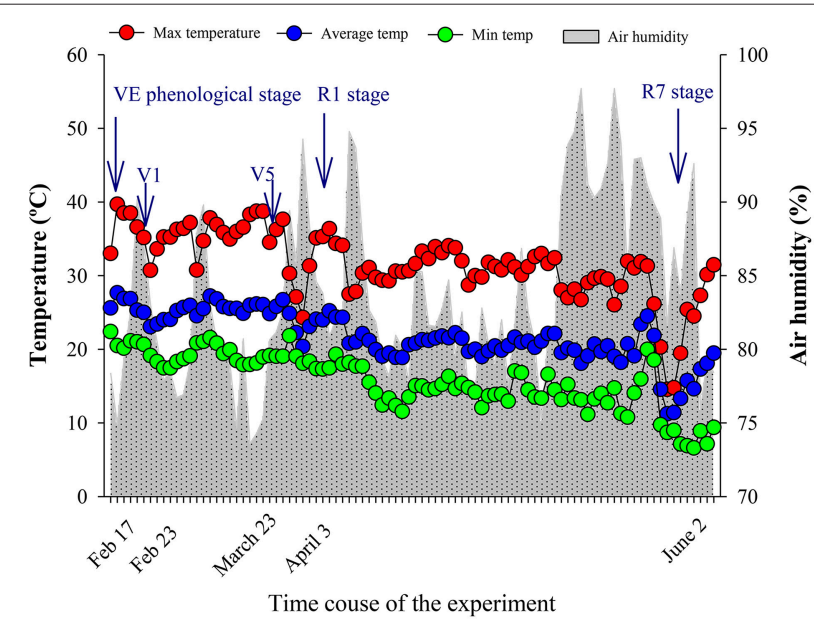

FIGURE 1 | Maximum, average, minimum temperature $\left({ }^{\circ} \mathrm{C}\right)$, and air humidity (\%) data during the experimental period. Vegetative and

reproductive phenological stages (VE, emergence-cotyledons above the soil surface; V1, first node-fully developed leaves at unifoliolate nodes, and V5, fifth nodule-five nodes on the main stem with fully developed leaves beginning with the unifoliolate nodes; R1, beginning bloom - one open flower at any node on the main stem and R7, beginning maturity-One normal pod on the main stem that has reached its mature pod color; Fehr et al., 1971). micronutrients, except to Ni. The concentration of $\mathrm{B}, \mathrm{Cu}, \mathrm{Fe}$, $\mathrm{Mn}$, and $\mathrm{Zn}$ varied, respectively, from 78 to $125 \mathrm{mg} \mathrm{kg}^{-1}$ of $\mathrm{B}$, 10.2 to $12.7 \mathrm{mg} \mathrm{kg}^{-1}$ of $\mathrm{Cu}, 329.9$ to $522 \mathrm{mg} \mathrm{kg}^{-1}$ of Fe, 227.5 to $302.8 \mathrm{mg} \mathrm{kg}^{-1}$ of $\mathrm{Mn}$, and from 106.8 to $167.9 \mathrm{mg} \mathrm{kg}^{-1}$ of $\mathrm{Zn}$, by increasing $\mathrm{Ni}$ rates from 0 to $540 \mathrm{mg} \mathrm{kg}^{-1}$. The application of $\mathrm{Ni}$ in the seeds influenced the concentration of this element in the leaves used for diagnosis (Table 2), in which this concentration varied from 0.07 to $1.22 \mathrm{mg} \mathrm{kg}^{-1}$, respectively, for $\mathrm{Ni}$ rates of 0 and $135 \mathrm{mg} \mathrm{kg}^{-1}$, which is the inflection point of the $\mathrm{Ni}$ rates.

The effect of the Ni rates positively affected the SPAD index, with values ranging from 27.8 to 31.5 , respectively, at $\mathrm{Ni}$ doses of 0 and $135 \mathrm{mg} \mathrm{kg}^{-1}$ (Figure 2), corresponding to $13 \%$ of increase on leaf greenness. An exponential effect for the SPAD value was observed, where the threshold was achieved at $\mathrm{Ni}$ rate of $135 \mathrm{mg} \mathrm{kg}^{-1}$. On the other hand, it was not observed significant effect between $\mathrm{N}$ content in the leaves and SPAD index taken on this leaves (dada not showed).

The application of $\mathrm{Ni}$ doses in the seeds also had a positive influence on the accumulation of $\mathrm{N}$ in the grains and aerial part of the soybean plants in the final reproductive phonological stage (R7; the beginning of grain maturity; Figures $3 \mathbf{A}, \mathbf{B})$ as compared to the control. The average accumulation of total $\mathrm{N}$ in the aerial part (green leaves, dry leaves, stems, and pods) was $136.5 \mathrm{mg}$ per plant, considering all $\mathrm{Ni}$ rates (from 45 to $540 \mathrm{mg} \mathrm{kg}^{-1}$ ). Accumulation of total $\mathrm{N}$ in the grains increased $35 \%$ with $\mathrm{Ni}$-seed treatment from 0 to $45 \mathrm{mg} \mathrm{kg}^{-1}$, and $16 \%$ by increasing $\mathrm{Ni}$ rates from 45 to $360 \mathrm{mg} \mathrm{kg}^{-1}$, in which the highest $\mathrm{Ni}$-seed dose

TABLE 2 | Concentration [Y] of nitrogen (N), phosphorus (P), potassium (K), calcium (Ca), magnesium (Mg), sulfur (S), boron (B), cupper (Cu), iron (Fe), manganese (Mn), nickel ( $\mathrm{Ni})$, and zinc ( $\mathrm{Zn}$ ) taken on the leaves of soybean cultivar BMX Potência RR, collected at R1 phenological stage (Fehr et al., 1971), as related to Ni seed treatments [X].

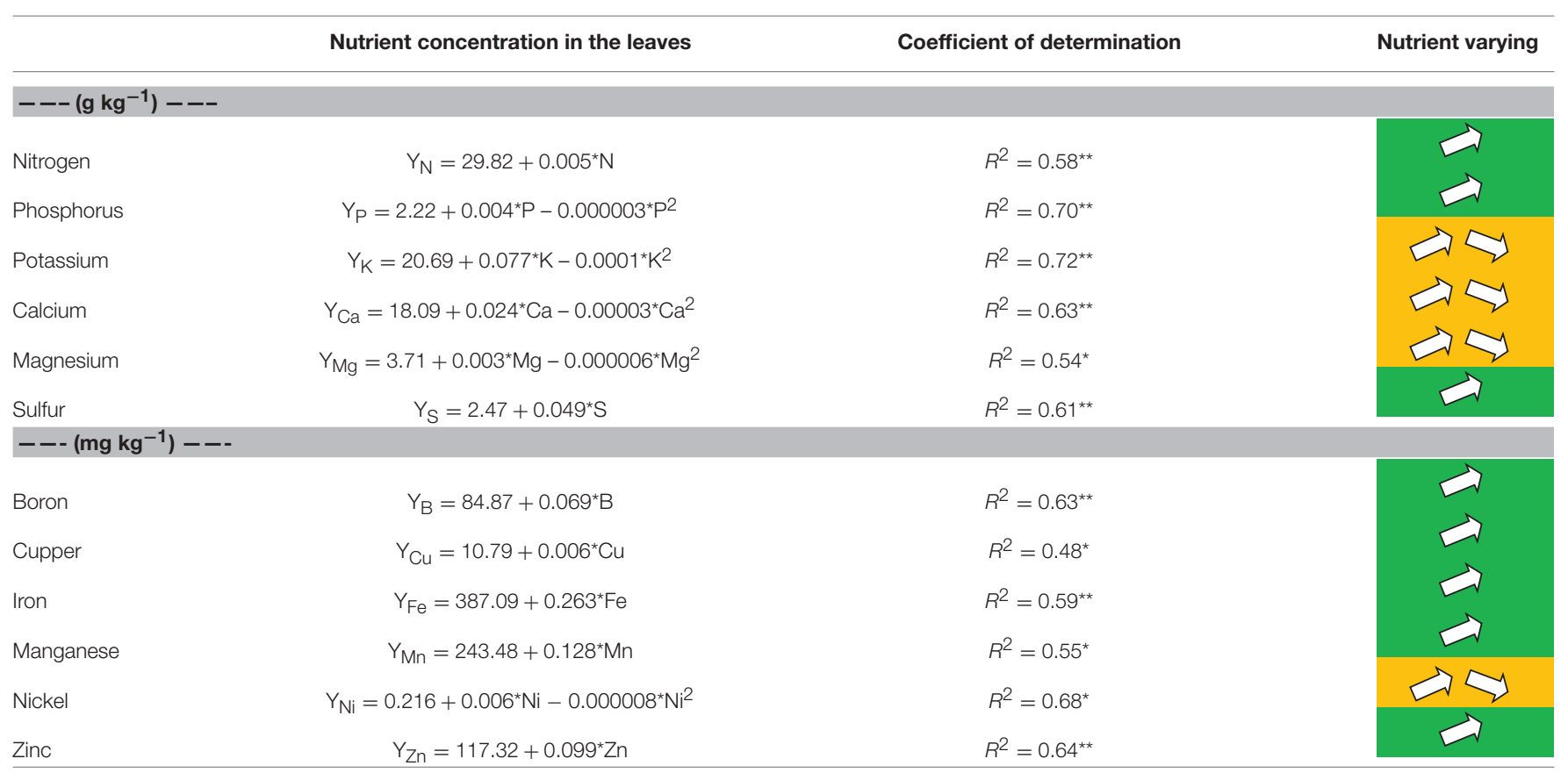

Mean ( $n=4$ biological replicates; Fisher Test, $p<0.01 .{ }^{*}$ is significant at 0.01 and ${ }^{*}$ is significant at 0.05 ). 
resulted in a lower total $\mathrm{N}$-accumulation, $5 \%$ lesser than the control.

The Ni rates applied in the seeds positively influenced the $\mathrm{Ni}$ content in the aerial parts collected in phenological stage

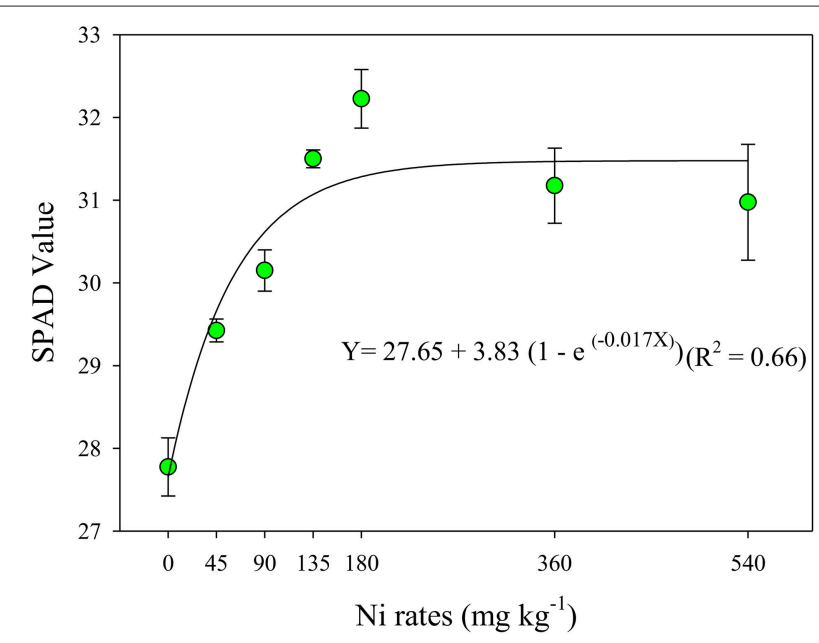

FIGURE 2 | SPAD value taken on the leaves of soybean cultivar BMX Potência RR, collected at R1 phenological stage (Fehr et al., 1971), as related to Ni seed treatments (rates). Relative chlorophyll concentration in the leaf used for nutrient analysis assessed by SPAD measurements. The readings were taken using the middle third of the diagnostic leaf of plants in phenological stage $\mathrm{R} 1$, and the average was computed of 30 readings per plant of four replicates per treatment. Mean $\pm \mathrm{SD}$. (Fisher Test, $p<0.01$ ).
R7. The Ni content in the aerial parts fit a linear regression model (Figure 3C), showing a direct and positive correlation with the rates applied $\left(R^{2}=0.95^{* * *}\right)$. However, for the accumulation of $\mathrm{Ni}$ in the grains, the effect was quadratic, in which the dose of $360 \mathrm{mg} \mathrm{kg}^{-1}$ resulted in the highest $\mathrm{Ni}$ accumulation $\left(R^{2}=0.97^{* * *}\right)$. Nickel contents in the seeds increased by $221 \%$ with $\mathrm{Ni}$ rates from 0 to $540 \mathrm{mg} \mathrm{kg}^{-1}$. On the other hand, it was observed Ni-accumulation in the grains of $262 \%$ by increasing $\mathrm{Ni}$ rates from 0 to $360 \mathrm{mg} \mathrm{kg}^{-1}$ (Figure 3D).

The BNF estimated by the technique of natural abundance of ${ }^{15} \mathrm{~N}$ (Table 3), by using the concentrations of $\delta^{15} \mathrm{~N}$ in the grains and aerial parts of soybean at R7 reproductive stage (phenological stage of fruit and seed ripening), as well as in the non-fixing plants (used as controls) showed values with respective $\delta^{15} \mathrm{~N}$ for $P$. miliaceum and $P$. canariensis of 6.05 and $5.14 \%$, respectively. These species (non-fixers of $N$ ) were grown in the same soil and climate conditions as the soybean plants. In the aerial part of the soybean plants, the concentrations of $\delta^{15} \mathrm{~N}$ ranged from 1.53 to 0.91 and the BNF varied from 61 to $70 \%$ on average, respectively, for $\mathrm{Ni}$ rates of 0 and $360 \mathrm{mg} \mathrm{kg}^{-1}$, without significant differences between the $\mathrm{Ni}$ rates applied (Table 3 ). However, analysis of the natural abundance of $\delta^{15} \mathrm{~N}$ in the grains indicated there was a difference in BNF of the treatments, with variation of $\delta^{15} \mathrm{~N}$ of 0.42 to -1.72 . The application of $45 \mathrm{mg}$ $\mathrm{kg}^{-1}$ of $\mathrm{Ni}$ via seeds indicated that $99 \%$ of the $\mathrm{N}$ accumulated in the grains came from BNF, while in the control treatment (none $\mathrm{Ni}$ application rate) the $\mathrm{N}$ fixation rate was only $77 \%$ (Table 3).

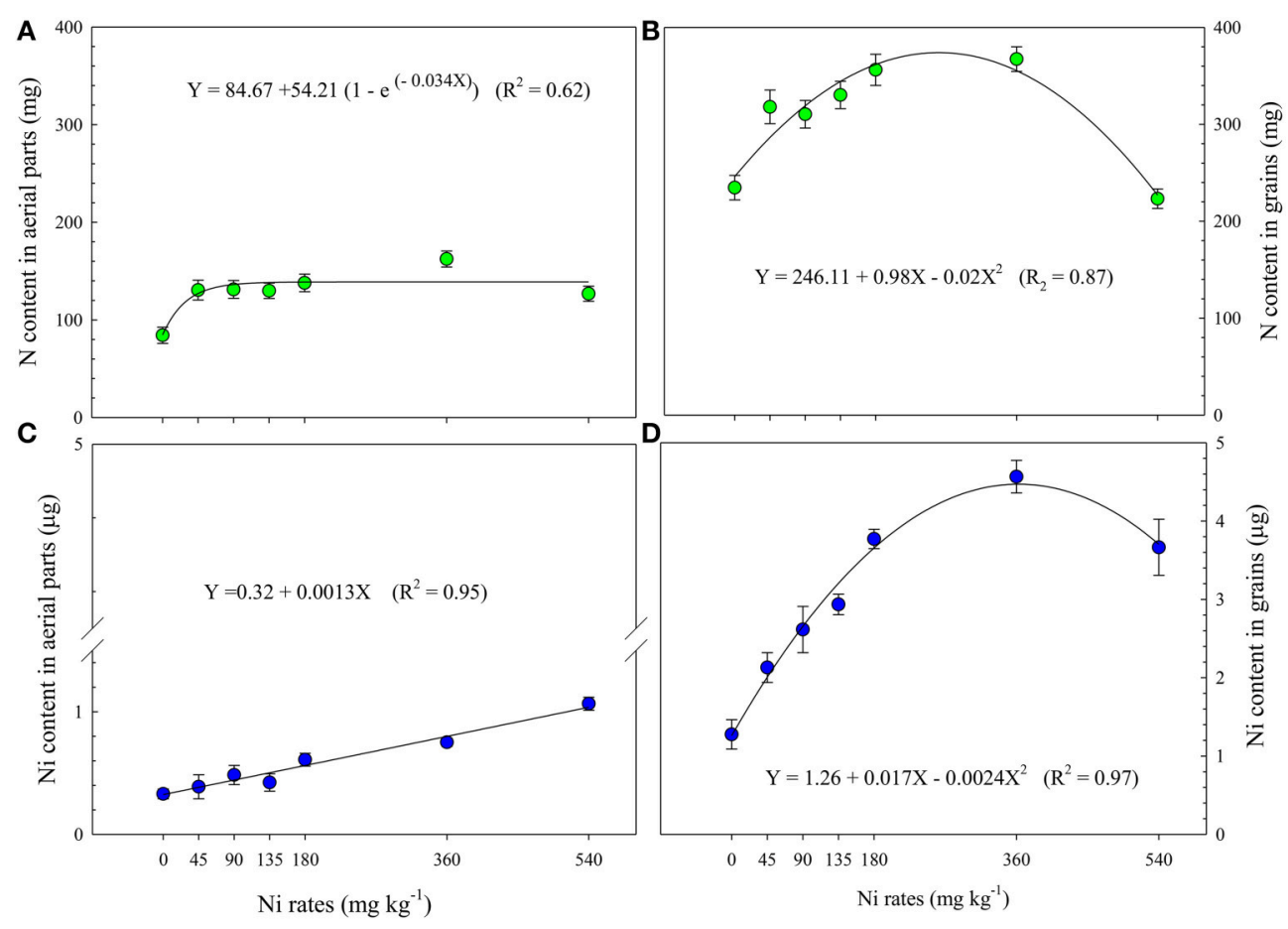

FIGURE 3 | Nitrogen content in the aerial parts (A) and in the grains (B) and nickel content in the aerial parts (C) and in the grains (D) of soybean cultivar BMX Potência RR, collected at R7 phenological stage (Fehr et al., 1971), as related to Ni seed treatments (rates). Four replicates per treatment. Mean \pm SD. (Fisher Test, $p<0.01)$. 
TABLE 3 | Natural abundance of ${ }^{15} \mathrm{~N}\left(\delta^{15} \mathrm{~N} \%\right.$ ) and estimation of BNF (\%) in the soybean plant (aerial parts and grain) and activity of reducing acetylene (ARA) in soybean nodules grown in greenhouse as related to the application of Ni rates via seed.

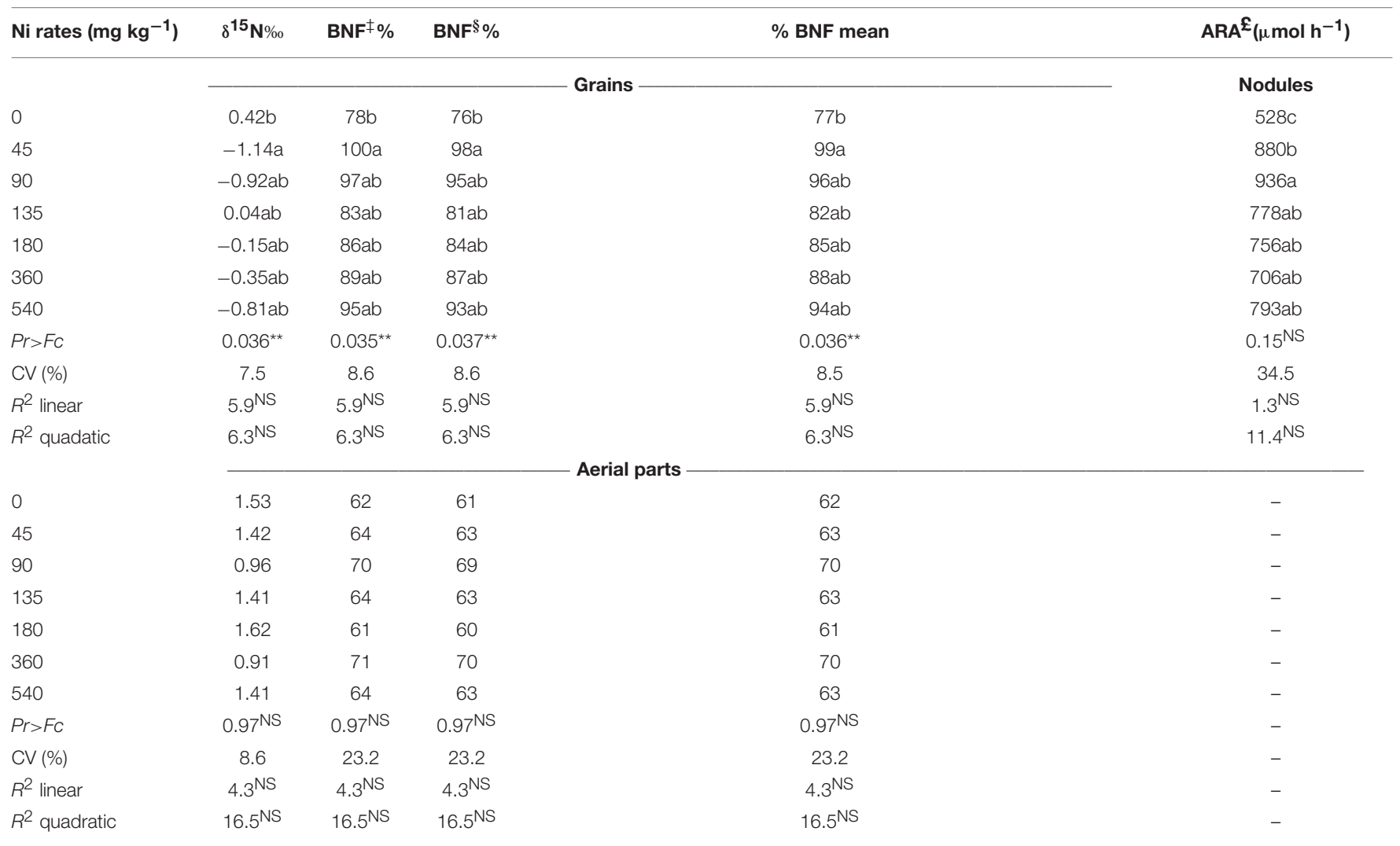

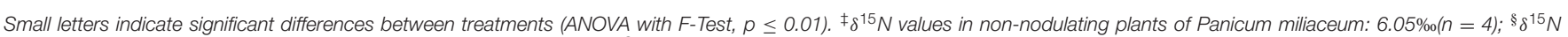

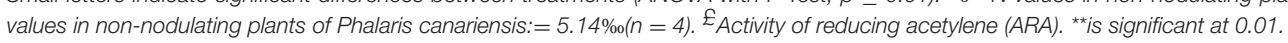

The activity of reducing acetylene (ARA) results did not show significant effect of Ni-seed treatment (Table 3). However, we found that $\mathrm{Ni}$ application of 45 and $90 \mathrm{mg} \mathrm{kg}^{-1}$ via the seeds resulted in respective increases of 67 and $77 \%$ in the nitrogenase activity in relation to the control. It was observed an effect of $\mathrm{Ni}$ seed treatments in urease activity. The ureolytic activity increased sharply up to Ni rate of $180 \mathrm{mg} \mathrm{kg}^{-1}$ and then leveled off at higher Ni supply (Figure 4). The urease activity increased by 40, 71, 118, and $143 \%$ in relation to the control, respectively, to Ni rates of 45 , 90,135 , and $180 \mathrm{mg} \mathrm{kg}^{-1}$.

It was observed a difference in aerial part dry weight (APDW) and grain dry weight (GDW) in function of the $\mathrm{Ni}$ doses applied in the seeds (Figures 5A,B). The APDW and GDW increased by 64 and $63 \%$, respectively, with increase in the $\mathrm{Ni}$ rate from 0 to $180 \mathrm{mg} \mathrm{kg}^{-1}$. However, GDW and APDW increased, respectively, by 84 and $51 \%$ in relation to the control at $45 \mathrm{mg} \mathrm{kg}^{-1} \mathrm{Ni}$ via seed treatment. On the other hand, it were observed reductions in the biomass yield by the aerial part and grains at $\mathrm{Ni}$ rates higher than $180 \mathrm{mg} \mathrm{kg}^{-1}$ (Figure 5). In relation to nodule mass (Figure 5B), although no significant variation was observed for the $\mathrm{Ni}$ rates, the fresh weight of the nodules increased with $\mathrm{Ni}$-seed application from 0 to $45 \mathrm{mg}$ $\mathrm{kg}^{-1}$ (Figure 6). The highest value was observed at the rate of $45 \mathrm{mg} \mathrm{kg}^{-1}$, the same rate that most favored the increase of the contribution of $\mathrm{BNF} \%$, i.e., that most increased the $\mathrm{BNF}$ efficiency (Table 3).

\section{DISCUSSION}

Early reports as related to increased efficiency of biologic nitrogen fixation (BNF) in legumes, including soybean plants, by supplying of cobalt (Co), molybdenum (Mo), and Bradyrhizobium strains seed treatment were published (Hungria et al., 2005, 2006; Campo et al., 2009). Even though there are many studies describing to the importance of nutritional aspects of sulfur (S), iron (Fe), Co, and Mo supply affecting symbiotic nitrogen fixation, the actual evidences on soybean seed treatment with nickel $(\mathrm{Ni})$ and its effect on BNF are unclear and scarce. Therefore, the purpose of the present research was to demonstrate that Ni supply to soybean plants by seed treatment can increase the symbiotic nitrogen fixation effectiveness, directly by the ${ }^{15} \mathrm{~N}$ natural abundance method $\left(\delta^{15} \mathrm{~N} \%\right.$ ) and by measurement of urease activity, as well as indirectly by nitrogenase (N-ase) activity.

Processes in the development of some legume symbioses on the biologic nitrogen fixation (BNF) specifically require calcium, cobalt, copper, iron, potassium, molybdenum, nickel, 
phosphorus, selenium, zinc, and boron. Therefore, the low supply of inorganic nutrients may affect effectiveness of nitrogen fixation and then reduce legume yield (O'Hara, 2001; Brear et al., 2013; González-Guerrero et al., 2014). In this sense, we observed that soybean seed treatment with $\mathrm{Ni}-$ together with $\mathrm{Co}$, Mo, and B. japonicum-increased nutrients and chlorophyll content (SPAD index) in the leaves, urease, and nitrogenase activities taken on the leaves and root nodules, respectively, as well as increased ${ }^{15} \mathrm{~N}$ fixation and $\mathrm{N}$ accumulation in the leaves and grains, which in turn result in the visual difference on plant growth from control as compared to Ni-seed treatment of $45 \mathrm{mg}$ $\mathrm{kg}^{-1}$ (Figure 6). It was also observed an increase in the dry weight of aerial parts and grains by $\mathrm{Ni}$-seed supply up to $180 \mathrm{mg} \mathrm{kg}^{-1}$.

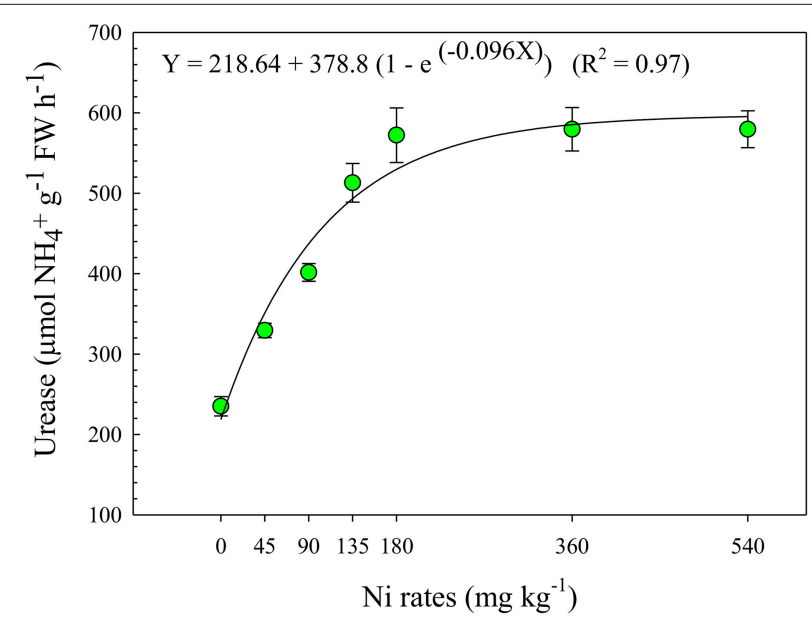

FIGURE 4 | Urease activity taken on the leaves of soybean cultivar BMX Potência RR, collected at R1 phenological stage (Fehr et al., 1971), as related to $\mathrm{Ni}$ seed treatments (rates). The assessments were taken using the middle third of the diagnostic leaf of plants in phenological stage R1, and the average was computed of four replicates per treatment. Mean \pm SD. (Fisher Test, $p<0.01$ ).
We observed a significant effect of the leaf concentrations of all nutrients evaluated in this study for the Ni doses applied via seeds (Table 2). The leaves were sampled at the R1 stage, when a large part of the nutrients in the leaves is remobilized-notably those elements highly mobile in the phloem-to reproductive structures, mainly the flowers, and subsequently to the pods and grains. Except for $\mathrm{N}$, the leaf concentrations of the macronutrients were within the intervals suggested as sufficient for soybean plants and so did not limit the plants' development (Jones, 2003). In relation to micronutrients, except for $\mathrm{Cu}$ the values measured in the diagnostic leaves were within the ranges

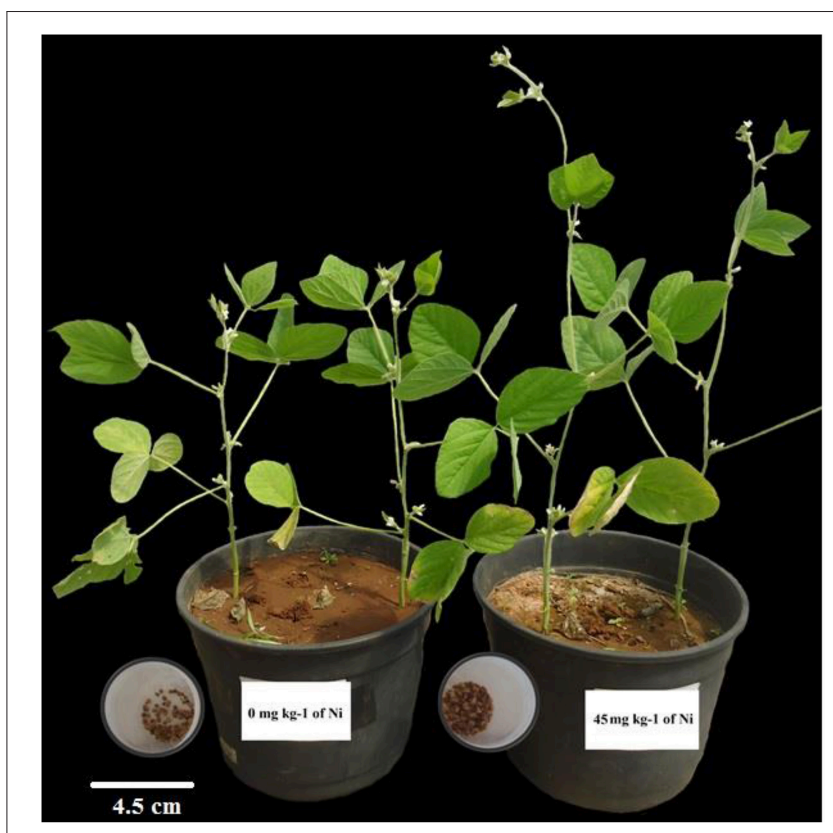

FIGURE 6 | Visual aspects of soybean cultivar BMX Potência RR growth at reproductive phonological stage (R1, Fehr et al., 1971) and its fresh nodules collected at this stage, as related to $\mathrm{Ni}$ seed treatments of control and $\mathrm{Ni}$ rate of $45 \mathrm{mg} \mathrm{kg}^{-1}$.
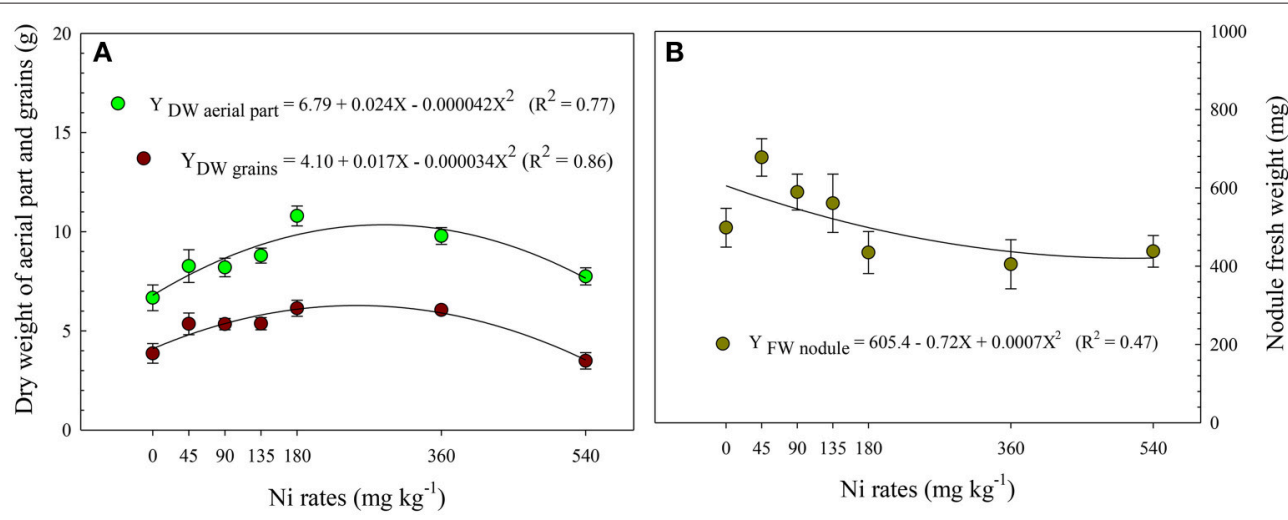

FIGURE 5 | Dry weight of aerial parts and grains (A) and fresh weight of nodules (B) of soybean cultivar BMX Potência RR as related to Ni seed treatments (rates). The nodules were collected at R1 phenological stage (Fehr et al., 1971), while aerial parts and grains were collected at phenological stage R7. The average was computed of four replicates per treatment. Mean \pm SD. (Fisher Test, $p<0.01$ ). 
established as suitable (Jones, 2003). According to Gerendas and Sattelmacher (1997) and Gerendas et al. (1999), the ions $\mathrm{Cu}^{2+}$ and $\mathrm{Zn}^{2+}$ exert an interionic effect of competitive inhibition with the $\mathrm{Ni}^{2+}$ in the nutrient absorption process, indicating that these three ions are absorbed through the same ion channels, like ZIP or NRAMP transporter (Lin et al., 2010). However, in this study the effect was inverse, i.e., the application of $\mathrm{Ni}$ rates raised the leaf concentrations of $\mathrm{Cu}$ and $\mathrm{Zn}$, suggesting that application of $\mathrm{Ni}$ in seeds might have had a positive influence by reducing this competitive inhibition (Gerendas and Sattelmacher, 1997; Gerendas et al., 1999) and improving soybean nutritional status.

The application of $\mathrm{Ni}$ via seeds proved to be a highly efficient alternative to enrich the concentration of this element in the grains (Figure 3D). The application of $\mathrm{Ni}$ by seed enrichment should mainly be considered in soils with low Ni levels, in which the plant's response to the element can be positive. It should be noted again that the content of $\mathrm{Ni}$ in the seeds should also be considered. In other studies, $\mathrm{Ni}$ concentrations similar to those observed in our research were reported for soybean grains by Kutman et al. (2013), who obtained Ni concentrations of 0.04-8.32 $\mathrm{mg} \mathrm{kg}^{-1}$ when studying the effect of foliar application.

It is known that $\sim 40 \%$ of the dry soybean is composed of protein, resulting in a high demand for $\mathrm{N}$, and that majority of this is supplied by BNF (Alves et al., 2003; Hungria et al., 2006; Luca et al., 2014). In this study, a low Ni rate $\left(45 \mathrm{mg} \mathrm{kg}^{-1}\right)$ stimulated BNF and the affect was most pronounced in the grains, in which it can be noticed that more of $90 \%$ of total $\mathrm{N}$ accumulated were derived from BNF (Table 3). The absence of response of $\mathrm{BNF}$ in the aerial part, on early vegetative satege, probably occurred because at the start of development of soybean plants, the symbiosis with bacteria is not yet totally established (Alves et al., 2003). The nodules are small and sparse, and the plant is just starting to establish the infection process, so the demand for $\mathrm{N}$, essential for vegetative growth, is low. In the V2V3 period (Fehr et al., 1971), the largest part of $\mathrm{N}$ is supplied by reserves in the cotyledons, while the absorption by the roots from the soil is still incipient (Alves et al., 2003). In this initial development phase of shoot formation, the soybean plants might have taken up more $\mathrm{N}$ from the soil, presenting higher delta ${ }^{15} \mathrm{~N}$ values, near those of the soil, since a large part of the $\mathrm{N}$ needed for their development was derived from the $\mathrm{N}$ available in the soil (Table 3).

On the other hand, in more advanced vegetative stages, when the bacterium-plant symbiosis is better established, the plants obtain most of the $\mathrm{N}$ needed from BNF, since the delta ${ }^{15} \mathrm{~N}$ values tend to approach zero, indicating that the $\mathrm{N}$ taken up and assimilated comes from atmospheric air (Guimaraes et al., 2008; Urquiaga et al., 2012). In this case, Ni exerts an important role in the BNF process, and the application of $\mathrm{Ni}$ in the seeds increased the BNF by an average of $10 \%$, making a significant contribution to the supply of $\mathrm{N}$, mainly in the grains (Table 3). It is known that in the BNF process, $\mathrm{Ni}$ acts as a structural component of hydrogenase, an enzyme responsible for recapturing the $\mathrm{H}_{2}$ that is generated by nitrogenase during the process of reducing $\mathrm{N}_{2}$. In the $\mathrm{BNF}$ process, nitrogenase breaks down $\mathrm{N}_{2}$ and transforms it into $\mathrm{NH}_{3}$ and $\mathrm{H}_{2}$ gas (Ureta et al., 2005). The formation of $\mathrm{H}_{2}$ by the nitrogenase indicates inefficient use of energy that can be used in fixation of $\mathrm{N}_{2}$. Furthermore, the high concentrations of $\mathrm{H}_{2}$ inhibit the activity of nitrogenase and consequently reduce the efficiency of BNF (Ureta et al., 2005). Therefore, the presence of Ni might have favored the activity of hydrogenase, recapturing more $\mathrm{H}_{2}$, increasing the energy efficiency of the process and hence optimizing the reduction of $\mathrm{N}_{2}$ and the entire BNF process. Thus, we can consider that there is a positive feedback between the activities of the hydrogenase and nitrogenase, in order to keep the BNF constant and efficient (Zhang et al., 2014).

The ARA is widely used for indirect measurement of the activity of nitrogenase ( $\mathrm{N}$-ase) in samples of plants, bacteria and isolated organisms (Boddey et al., 2001). In this study, although the ARA results were not significant, we did observe a response tendency with the presence of $\mathrm{Ni}$. The absence of a statistical difference between the treatments can be explained by the variability of the results, with a high coefficient of variation between the means of the treatments of $\sim 35 \%$. Besides, it has been pointing out that many factors might interfere in this analysis and results, among them temperature, quantity of $\mathrm{O}_{2}$ in the flask, concentration of acetylene, and limit of detection of the equipment, preventing a statistical difference between the doses (Boddey et al., 2001; Guimaraes et al., 2008).

In general, the presence of $\mathrm{Ni}$ significantly enhanced the BNF by the soybean plants and the metabolism of $\mathrm{N}$, favoring the accumulation of $\mathrm{N}$ in the grains and aerial part, which can be associated with chlorophyll content (SPAD index) taken on the leaves (Figure 2). Kutman et al. (2013) reported an increase of $30 \%$ in the $\mathrm{N}$ concentration in the new leaves of soybean plants after external application of $\mathrm{Ni}$. It should be considered also that in the process of remobilizing $\mathrm{N}$ in old leaves, proteins, and amino acids are degraded in the mitochondria (e.g., action of arginase), resulting in the formation of urea in the cytosol (Gerendas and Sattelmacher, 1997; Gerendas et al., 1999; Cakmak et al., 2010; Witte, 2011). Ni promotes an increase of urease activity, favoring the metabolism of $\mathrm{N}$, and enhancing the remobilization of $\mathrm{N}$ from the old to new leaves (Kutman et al., 2013). This also confirms our results observed for the increased activity of urease by applying Ni on seeds (Figure 4).

The application of Ni positively influenced the soybean yield. This yield was highest at Ni rates of 45 and $90 \mathrm{mg} \mathrm{kg}^{-1}$, while at higher rates, such as $540 \mathrm{mg} \mathrm{kg}^{-1}$, the grain yield declined, probably due to the toxic effect of $\mathrm{Ni}$ (Figure 5). Very few studies have been published on the effect of applying nickel via seeds on the development of soybean plants. Most studies report the addition of this element in the soil or a nutrient solution (Kutman et al., 2013), foliar application (Nyczepir and Wood, 2012), or even have considered that the quantity of $\mathrm{Ni}$ in the soil and seeds is sufficient to supply the plants' needs. Kutman et al. (2013) observed that application of this micronutrient in the seeds did not promote increased grain productivity, although it did influence the activity of some enzymes analyzed.

\section{CONCLUSIONS}

The results of this study provide relevant information because show that the grain yield per plant increased at the lowest Ni rates 
applied in the seeds. As also shown, Ni influenced the activity of enzymes that take part in the metabolism of $\mathrm{N}$, and enhanced the biological fixation of $\mathrm{N}$, besides increasing the accumulation of $\mathrm{N}$ by the plants.

In general, the presence of $\mathrm{Ni}$ in the seeds stimulated the BNF process, probably due to the higher activity of the enzyme hydrogenase. Certainly when the hydrogenase activity increased-confirmed indirectly by determining the activity of nitrogenase (by the indirect ARA), the energy efficiency of BNF increased. The increased contribution of BNF was reflected in higher accumulation of total $\mathrm{N}$ in the aerial parts and grains and the increase of urease activity. These benefits, along with the savings of photoassimilates, resulted higher production of APDW and grain yield. Finally, the application of $\mathrm{Ni}$ in the seeds should mainly be adopted in sandy soils having low levels of this element and in soils with medium and sandy texture after correction with lime, a common and necessary practice in soils in Cerrado regions in Brazil. The application of $\mathrm{Ni}$ via seed treatment

\section{REFERENCES}

Alves, B. J. R., Boddey, R. M., and Urquiaga, S. (2003). The success of BNF in soybean in Brazil. Plant Soil 252, 1-9. doi: 10.1023/A:10241919 13296

Barrie, A., and Prosser, S. J. (1996). "Automated analysis of light-element stable isotopes by isotope ratio mass spectrometry," in Mass Spectrometry of Soils, eds T. W. Boutton and S. Yamasaki (New York, NY: Marcel Dekker), 1-46.

Boddey, R. M., Polidoro, J. C., Resende, A. S., Alves, B. J. R., and Uurquiaga, S. (2001). Use of the ${ }^{15} \mathrm{~N}$ natural abundance technique for the quantification of the contribution of $\mathrm{N}_{2}$ fixation to grasses and cereals. Aust. J. Plant Physiol. 28, 889-895.

Brear, E. M., Day, D. A., and Smith, P. M. C. (2013). Iron: an essential micronutrient for the legume - rhizobium symbiosis. Front. Plant Sci. 4:359. doi: 10.3389/fpls.2013.00359

Brito, M. M. P., Muraoka, T., and Silva, E. S. (2009). Uptake rate of nitrogen from soil and fertilizer, and $\mathrm{n}$ derived from symbiotic fixation in cowpea (Vigna unguiculata (L.) walp.) and common bean (Phaseolus vulgaris L.) determined using the ${ }^{15} \mathrm{~N}$ isotope. Rev. Bras. Cienc. Solo. 33, 895-905. doi: 10.1590/S010006832009000400014

Cadisch, G., Hairiah, K., and Giller, K. E. (2000). Applicability of the natural ${ }^{15} \mathrm{~N}$ abundance technique to measure $\mathrm{N}_{2}$ fixation in Arachis hypogaea grown on an Ultisol. Neth. J. Agric. Sci. 48: 31-45. doi: 10.1016/S1573-5214(00) 80003-2

Cakmak, I., Pfeiffer, W. H., and McClafferty, B. (2010). Biofortification of durum wheat with zinc and iron. Cereal Chem. 87, 10-20. doi: 10.1094/CCHEM-87-10010

Campo, R. J., Araujo, R. S., and Hungria, M. (2009). Nitrogen fixation with the soybean crop in Brazil: compatibility between seed treatment with fungicides and bradyrhizobial inoculants. Symbiosis 48, 154-163. doi: 10.1007/BF03179994

Cantarella, H., van Raij, B., and Quagiio, J. A. (1998). Soil and plant analyses for lime and fertilizer recommendations in Brazil. Commun. Soil Sci. Plant Anal. 29, 1691-1706. doi: 10.1080/00103629809370060

Companhia Nacional de Abastecimento (Conab) (2014). Acompanhamento da Safra Brasileira de Grãos - Safra 2013/14. (2014). Décimo Segundo Levantamento. 1, 1-127.

Embrapa (2006). Sistema Brasileiro de Classificação de Solos. Rio de Janeiro: Embrapa Solos.

Embrapa (2011). Tecnologias de Produção de Soja. Região Central do Brasil 2012 e 2013. Londrina: Embrapa Soja. is a viable strategy, since this element can be applied along with the other two micronutrients that are closely associated with the BNF process, Mo and Co. The results of present study demonstrate the contribution of $\mathrm{Ni}$ to the BNF process and to higher grain yield. However, other experiments, under controlled and field conditions, with lower $\mathrm{Ni}$ rates are necessary.

\section{AUTHOR CONTRIBUTIONS}

All authors listed, have made substantial, direct and intellectual contribution to the work, and approved it for publication.

\section{ACKNOWLEDGMENTS}

This work was funded by Coordenação de Aperfeiçoamento de Pessoal de Nível Superior (CAPES-Brazil). GC thanks CAPES and JL thanks FAPESP (São Paulo Research Foundation; 2007/58406-1) for the scholarships granted.
Fageria, N. K., and Stone, L. F. (2008). "Micronutrient deficiency problems in South America," in Micronutrient Deficiencies in Global Crop Production, ed B. J. Alloway (Dordrecht: Springer), 245-266.

Fehr, W. E., Caviniss, C. E., Burmood, D. T., and Pennington, J. S. (1971). Stage of development descriptons for soybeans, Glycine max (L.) Merrill. Crop Sci. 11, 929-931.

Gerendas, J., Polacco, J. C., Freyermuth, S. K. A., and Sattelmacher, B. (1999). Significance of nickel for plant growth and metabolism. J. Plant. Nutr. Soil Sci. 162, 241-256. doi: 10.1002/(SICI)1522-2624

Gerendas, J., and Sattelmacher, B. (1997). Influence of Ni supply on growth and nitrogen metabolism of Brassica napus L. grown with $\mathrm{NH}_{4} \mathrm{NO}_{3}$ or urea as $\mathrm{N}$ source. Ann. Bot. 83, 65-71. doi: 10.1006/anbo.1998.0789

González-Guerrero, M., Matthiadis, A., Sáez, A., and Long, T. A. (2014). Fixating on metals: new insights into the role of metals in nodulation and symbiotic nitrogen fixation. Front. Plant Sci. 5:45. doi: 10.3389/fpls.2014.00045

Guimaraes, A. P., Morais, R. F., Urquiaga, S., Boddey, R. M., and Alves, B. J. R. (2008). Bradyrhizobium strain and the ${ }^{15} \mathrm{~N}$ natural abundance quantification of biological $\mathrm{N}_{2}$ fixation in soybean. Sci. Agric. 65, 516-524. doi: 10.1590/S010390162008000500011

Hatfield, J., Egli, D. B., Leggett, J. E., and Peaslee, D. E. (1974). Effect of appied nitrogen on the nodulation and early growth of soybeans (Glycine max (L) MERR.). Agron. J. 66, 112-114.

Hogan, M. E., Swift, I. E., and Done, J. (1983). Urease assay and ammonia release from leaf tissues. Phytochemistry 22, 663-667. doi: 10.1016/S00319422(00)86958-7

Hungria, M., Franchini, J., Campo, R., Crispino, C., Moraes, J., Sibaldelli, R., et al. (2006). Nitrogen nutrition of soybean in Brazil: contributions of biological $\mathrm{N}_{2}$ fixation and $\mathrm{N}$ fertilizer to grain yield. Can. J. Plant Sci. 86, 927-939. doi: 10.4141/P05-098

Hungria, M., Franchini, J. C., Campo, R. I., and Graham, P. H. (2005). "The importance of nitrogen fixation to soybean cropping in South America," in Nitrogen Fixation: Origins, Applications and Research Progress, ed W. E. Newton (Dordrecht: Springer), 25-42.

Jensen, E. S., and Hauggaard-Nielsen, H. (2003). How can increased use of biological $\mathrm{N}_{2}$ fixation in agriculture benefit the environment? Plant Soil 252, 177-186. doi: 10.1023/A:1024189029226

Jones, J. B. Jr. (eds.). (2003). Agronomic Handbook: Management of Crops, Soils, and Their Fertility. Boca Raton, FL: CRC Press.

Klucas, R. V., Hanus, F. J., Russell, S. A., and Evans, H. J. (1983). Nickel: a micronutrient element for hydrogen-dependent growth of Rhizobium japonicum and for expression of urease activity in soybean leaves. Proc. Natl. Acad. Sci. U.S.A. 80, 2253. doi: 10.1073/pnas.80.8.2253 
Kutman, B. Y., Kutman, U. B., and Cakmak, I. (2013). Nickel-enriched seed and externally supplied nickel improve growth and alleviate foliar urea damage in soybean. Plant Soil 363, 61-75. doi: 10.1007/s11104-012-1 284-6

Lin, W., Chai, J., Love, J., and Fu, D. (2010). Selective electrodiffusion of zinc ions in a Zrt-, Irt-like protein, ZIPB. J. Biol. Chem. 285, 39013-39020. doi: 10.1074/jbc.M110.180620

Luca, M. J., Nogueira, M. A., and Hungria, M. (2014). Feasibility of lowering soybean planting density without compromising nitrogen fixation and yield. Agron. J. 106, 2118-2124. doi: 10.2134/agronj14.0234

Malavolta, E., Vitti, G. C., and Oliveira, S. A. (1997). Avaliação do Estado Nutricional das Plantas. Princípios e Aplicações, 2nd Edn. Piracicaba: Potafos.

Nyczepir, A. P., and Wood, B. W. (2012). Foliar nickel application can increase the incidence of peach tree short life and consequent peach tree mortality. HortScience 47, 224-227.

O'Hara, G. W. (2001). Nutritional constraints on root nodule bacteria affecting symbiotic nitrogen fixation: a review. Aust. J. Exp. Agric. 41, 417-433. doi: 10.1071/EA00087

Peoples, M. B., Faizah, A. W., Rerkasem, B., and Herridge, D. F. (1989). Methods for Evaluating Nitrogen Fixation by Nodulated Legumes in the Field. Canberra: ACIAR. (ACIAR Monograph, 11).

Pierozan, C., Favarin, J. L., Almeida, R. E. M., Oliveira, S. M., Lago, B. C., and Trivelin, P. C. O. (2015). Uptake and allocation of nitrogen applied at low rates to soybean leaves. Plant Soil 39, 83-94. doi: 10.1007/s11104-015-2 468-7

Quaggio, J. A., Van Raij, B., and Malavolta, E. (1985). Alternative use of SMP buffer solution to determine lime requirement of soils. Commun. Soil Sci. Plant Anal. 16, 245-260. doi: 10.1080/00103628509 367600

SAS Institute (2009). The SAS System for windows. v. 9.2. Cary, NC: SAS Institute. Sentelhas, P. C., Battisti, R., Câmara, G. M. S., Farias, J. R. B., Hampf, A. C., and Nendel, C. (2015). The soybean yield gap in Brazil - magnitude, causes and possible solutions for sustainable production. J. Agric. Sci. 153, 1394-1411. doi: $10.1017 /$ S0021859615000313
Seregin, I. V., and Kozhevnikova, A. D. (2006). Physiological role of nickel and its toxic effects on higher plants. Russ. J. Plant Physiol. 53, 257-277. doi: $10.1134 /$ S1021443706020178

Shearer, G., and Kohl, D. H. (1986). $\mathrm{N}_{2}$-fixation in field settings: estimations based on natural ${ }^{15} \mathrm{~N}$ abundance. Aust. J. Plant Physiol. 13, 699-756.

Ureta, A. C., Imperial, J., Ruiz-Argueso, T., and Palacios, J. M. (2005). Rhizobium leguminosarum Biovar viciae symbiotic hydrogenase activity and processing are limited by the level of nickel in agricultural soils. Appl. Environ. Microbiol. 71, 7603-7606. doi: 10.1128/AEM.71.11.7603-7606.2005

Urquiaga, S., Xavier, R. P., Morais, R. F., Batista, R. B., Sshultz, N., Leite, J. M., et al. (2012). Evidence from field nitrogen balance and ${ }^{15} \mathrm{~N}$ natural abundance data for the contribution of biological $\mathrm{N}_{2}$ fixation to Brazilian sugarcane varieties. Plant Soil 356, 5-21. doi: 10.1007/s11104-011-1016-3

Van Raij, B., de Andrade, J. C., Cantarella, H., and Quaggio, J. A. (2001). Análise Química Para Avaliação da Fertilidade de Solos Tropicais. Campinas: Instituto Agronômico, 285.

Witte, C. P. (2011). Urea metabolism in plants. Plant Sci. 180, 431-438. doi: 10.1016/j.plantsci.2010.11.010

Zhang, X., Sherman, D. M., and Sherman, L. A. (2014). The uptake hydrogenase in the unicellular diazotrophic Cyanobacterium cyanothece sp. Strain PCC 7822 protects nitrogenase from oxygen toxicity. J. Bacteriol. 196, 840-849. doi: $10.1128 /$ JB. $01248-13$

Conflict of Interest Statement: The authors declare that the research was conducted in the absence of any commercial or financial relationships that could be construed as a potential conflict of interest.

Copyright (c) 2016 Lavres, Castro Franco and de Sousa Câmara. This is an openaccess article distributed under the terms of the Creative Commons Attribution License (CC BY). The use, distribution or reproduction in other forums is permitted, provided the original author(s) or licensor are credited and that the original publication in this journal is cited, in accordance with accepted academic practice. No use, distribution or reproduction is permitted which does not comply with these terms. 